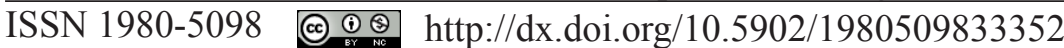

\title{
INTENSIVE MANAGEMENT FOR OPTIMIZING THE PRODUCTION OF HIGH-VALUE LOGS OF PINE FORESTS IN SOUTHERN BRAZIL
}

\author{
MANEJO INTENSIVO PARA OTIMIZAÇÃO DA PRODUÇÃO DE TORAS GROSSAS EM \\ POVOAMENTOS DE PINUS NO SUL DO BRASIL
}

\author{
Hassan Camil David ${ }^{1}$ Sylvio Péllico Netto ${ }^{2}$ Julio Eduardo Arce ${ }^{2}$ Antônio P. F. Woycikievicz ${ }^{3}$ \\ Emanuel J. G. de Araújo ${ }^{4}$ Rodrigo O. V. de Miranda ${ }^{5}$
}

\begin{abstract}
The best decision-making is a difficult task in forest management because it involves a large number of market and production variables. We simulated the growth and yield of loblolly pine in high-quality sites, aiming to indicate thinning regimes and planting densities that maximize the production of large diameter $\operatorname{logs}$ (minor diameter $>35 \mathrm{~cm}$ ), as well as economically evaluating such regimes. We used the software OpTimber-LP for forest optimization problems. Simulations involved four planting densities $(1,111 ; 1,600$; 2,000; and 2,500 plants/ha); three thinnings with different weights, frequencies and ages of application; and clear cut at 25 years. Such combinations totalized in 2,916 simulated regimes. We computed ANPV assuming variations in interest rates, besides costs of production and returns resulting from thinnings and from clear cut. The findings indicated great productions of large diameter logs in regimes with low planting densities. Heavy thinnings ( $60 \%$ removal of trees) highlighted by being ideal to almost all regimes, mainly those ones with densities of 2,000 and 2,500 plants/ha. Heavy intensity also was ideal to the first thinning, regardless the planting density. The most productive regimes presented large diameter log volumes ranging from 480 to $260 \mathrm{~m}^{3} / \mathrm{ha}$, for regimes with 1,111 and 2,500 plants/ha, respectively. ANPV ranged from $\sim 1.300$ to $\sim 2.100 \mathrm{R} \$ /$ ha. As conclusion, less dense regimes provide largest productions in large diameter log, but the lowest productions in total volume; as consequence, ANPV was larger in denser regimes, once the revenue obtained from high-value logs did not overcome that one obtained from finer (and consequently cheaper) logs. High-density regimes may produce less timber volume due to only one improper thinning, whereas low-density stands may have production really affected when are subjected to consecutive improper thinnings.
\end{abstract}

Keywords: growth and yield simulator; operational research; thinning regimes; planting density.

\section{RESUMO}

A melhor tomada de decisão é uma tarefa difícil no manejo florestal, pois envolve um grande número de variáveis de mercado e de produção. Simulou-se o crescimento e produção de Pinus taeda L. em sítios altamente produtivos, com objetivo de indicar regimes de desbaste e densidades de plantio que maximizam a produção de toras grossas (diâmetro da ponta fina $>35 \mathrm{~cm}$ ), bem como avaliá-los economicamente.

1 Engenheiro Florestal, MSc., Estudante de doutorado, Departamento de Ciências Florestais, Setor de Ciências Agrárias, Universidade Federal do Paraná, Av. Pref. Lothário Meissner, 632, Jardim Botânico, CEP 80210-170, Curitiba (PR), Brasil. hassancamil@gmail.com

2 Engenheiro Florestal, Dr., Professor do Departamento de Ciências Florestais, Setor de Ciências Agrárias , Universidade Federal do Paraná, Av. Pref. Lothário Meissner, 632, Jardim Botânico, CEP 80210-170, Curitiba (PR), Brasil. sylviopelliconetto@gmail.com / jarce@ufpr.br

3 Engenheiro Florestal, Mestrando em Engenharia Florestal, Departamento de Ciências Florestais, Setor de Ciências Agrárias, Universidade Federal do Paraná, Av. Pref. Lothário Meissner, 632, Jardim Botânico, CEP 80210-170, Curitiba (PR), Brasil. antoniof.w@gmail.com

4 Engenheiro Florestal, Dr., Professor do Departamento de Silvicultura, Universidade Federal Rural do Rio de Janeiro, BR 465, km 07, CEP 23890-000, Seropédica (RJ), Brasil. ejgaraujo@gmail.com

5 Engenheiro Florestal, Dr., Professor do Departamento de Engenharia Florestal, Setor de Ciências Agrárias e Ambientais, Universidade Estadual do Centro-Oeste, CEP 84500-000, Irati (PR), Brasil. rov_miranda@yahoo.com.br

Recebido para publicação em 6/09/2016 e aceito em 11/08/2017

Ci. Fl., v. 28, n. 3, jul. - set., 2018 
O software OpTimber-LP para otimização de problemas florestais foi usado. As simulações envolveram quatro densidades de plantio $(1.111 ; 1.600 ; 2.000$; e 2.500 plantas/ha); três desbastes com diferentes pesos, frequências e idades de aplicação; e corte raso aos 25 anos. Essas combinações totalizaram em 2.916 regimes de manejo. VPLA foi calculado com variação de taxas de interesse e considerando custos de produção e retornos provenientes de desbastes e do corte raso. Os resultados indicaram maior produção de toras grossas em regimes com menores densidades de plantio. A intensidade de desbaste de $60 \%$ destacou-se por ter sido ideal para quase todos os processos, principalmente nas densidades de 2.000 e 2.500 plantas/ha. Essa intensidade também foi ideal para o primeiro desbaste, independentemente da densidade de plantas. A produção nos melhores regimes variou de 480 e $260 \mathrm{~m}^{3} /$ ha, para as densidades de 1.111 e 2.500 plantas/ ha, respectivamente. VPLA variou de $\sim 1.300$ a $\sim 2.100 \mathrm{R} \$ /$ ha. Como conclusão, regimes de manejo menos densos propiciaram maior produção de toras grossas, porém, menor em volume total; como consequência, o VPLA foi maior para os regimes mais densos, uma vez que a receita obtida pela produção de toras de alto valor não compensou a receita de toras mais finas (que também são mais baratas). Regimes com alta densidade podem fracassar com um único primeiro desbaste errado, enquanto regimes com menor densidade podem ter produção realmente prejudicada quando são sujeitos a consecutivos desbastes errados.

Palavras-chave: simulador de crescimento e produção; pesquisa operacional; regimes de desbaste; densidade de plantio.

\section{INTRODUCTION}

Forest management and silviculture are activities that always involve decision-making taken basing on technical analysis or even on manager's empirical knowledge. Forest production contemplates a large number of variables whose interactions oftentimes turn into a complex situation. A forest manager that starts tree cultivation first must define the planting density per unit area. In southern Brazil, for example, pine forests are planted adopting from 1,111 up to 2,500 plants/ha. The increase of tree density makes the forest to reach earlier the competition by water, light and soil nutrients, resulting in self-thinning. Knowing that, loss of wood by mortality (self-thinning) must be avoided with intervention of artificial thinnings.

Despite the thinning effects are quite known on pine cultivations, the intensity, time, and type of thinnings are not easily determined, mainly for production of high-value logs, whose diameters are larger than the normal. The reason of that difficulty is because tree growth depends on several factors, including site index, plant density, species, and age of the forest, among others. These variables combined generate various possibilities to manage a forest, but one, and only one of them reaches the optimal production, since they present distinct growth rates and stocking just by changing the thinning regimes (SOALLEIRO; GONZALEZ; SCHRÖDER, 2000; PALAHÍ; PUKKALA, 2003; PUKKALA; MIINA, 2013; DAVID et al., 2017b). Thinnings play an important role in the forests destined to production of high-value logs, as venner and sawlogs. This silvicultural technique can increase diameter growth rates of the remaining trees once stagnated in condition of high density. In Brazil, pine forests also are thinned to control plagues as wood wasp (Sirex noctilio F.), capuchin monkey (Sapajus nigritus Goldfulls), as well to control forest fires, contributing thus for the forest maintenance (BORDEAUX; LORENZ; DEAN, 2012; LIEBSCH et al., 2015).

In this paper, we simulated the growth and yield of 2,916 loblolly pine (Pinus taeda L.) forests managed up to 25 years old. The aim was to indicate silvicultural practices (thinning regimes and planting densities) that maximize the production of large diameter logs (minor diameter $>35 \mathrm{~cm}$ ). We also performed an economic assessment and sensitivity analysis to evaluate the feasibility of the best management regimes. We considered four planting densities and application of three thinnings, which ranged in intensity and age of application. The simulations were performed considering a highly productive site index. 


\section{MATERIALS AND METHOD}

\section{Growth and yield simulation}

This research consisted of simulating the growth and yield of loblolly pine forests in order to evaluate the production of large diameter $\operatorname{logs}$ (minor diameter $>35 \mathrm{~cm}$ ). The scenarios were simulated using the operational research software OpTimber-LP ${ }^{\circledR}$, developed by the company OpTimber Optimization and Informatics. This software has linked to its internal system the software SisPinus ${ }^{\circledR}$, which is a growth and yield simulator of pine plantations in southern Brazil (CORTE; SANQUETTA, 2007). Oliveira (2011), illustrates some applications and shows modeling issues of the software SisPinus ${ }^{\circledR}$.

We adopted management regimes (without considering pruning) with four planting densities commonly used in pine plantations in the south of Brazil: 1,111; 1,600; 2,000; and 2,500 plants/ha. In addition, the simulated regimes were thinned three times, in which the first may be applied between 7-9 years, the second between 13-15 years and the third between 18-20 years old. The first thinning was always mixed, combining systematic (at every fifth line) thinning and from below, whereas the other ones were always thinnings from bellow, removing $30 \%, 45 \%$, or $60 \%$ thinner trees. All the simulated regimes were clear-cut at 25 years old. Figure 1 shows the interaction between all the employed variables (planting densities, intensity and age of application of the thinning), which totalized in 2,916 management regimes.

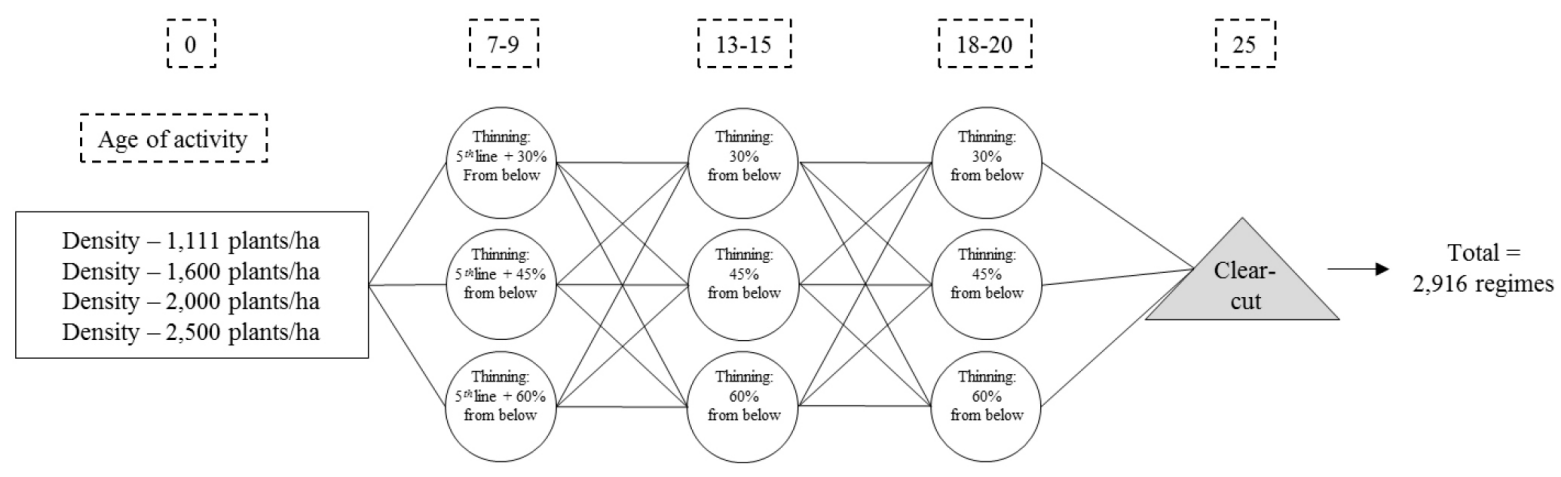

FIGURE 1: Management regimes simulated varying planting density and thinning regimes.

FIGURA 1: Regimes de manejo simulados variando densidade de plantio e regimes de desbaste.

The software OpTimber-LP ${ }^{\circledR}$ allows to embed a dominant height growth equation, thus we simulated the management regimes referencing the most productive site index found by David et al. (2015), for Pinus taeda in southern Brazil. Such site index corresponds to a dominant height around $28 \mathrm{~m}$ at the reference age of 15 years. In addition, this software presents taper functions that allowed us to estimate $\log$ volume following log dimensions previously defined. The sum of log volumes resulted in the total volume of the simulated regimes.

Although we are focused in the production of large diameter logs (minor diameter $>35 \mathrm{~cm}$ ), we also presented total volume of the most productive simulated regimes. In the south of Brazil, logs with minor diameter larger than $35 \mathrm{~cm}$ are commonly sold for veneer mills, as consequence are highly valued in relation to other smaller diameter logs. After simulating the production of the 2,916 management regimes, we performed an economic assessment and sensitivity analysis in order to estimate profitability under different interest rates.

\section{Economic assessment and sensitivity analysis}

We employed a discounted cash flow method in this research, which is an evaluation proper to our case that involves variations of cash flows among the simulated regimes (SILVA; JACOVINE; VALVERDE, 2005). We first calculated Net Present Value (NPV) [1] and then calculated Annualized Net Present Value (ANPV) [2] of the five most productive regimes in each planting density; its use in forestry is addressed 
by Acuña and Drake (2003). According to Dossa et al. (2000), ANPV is employed in mid- and long-term investments and can be computed by multiplying the NPV by a capital recovery factor, as follows:

$$
\begin{aligned}
& N P V=\sum_{j=0}^{n} R_{j} \cdot(1+i)^{-j}-\sum_{j=0}^{n} C_{j} \cdot(1+i)^{-j} \\
& A N P V=N P V \cdot\left[\frac{i \cdot(1+i)^{n}}{(1+i)^{n}-1}\right]
\end{aligned}
$$

Where: $\mathrm{Rj}=$ return in the $\mathrm{j}$-th periods; $\mathrm{Cj}=$ cost in the $\mathrm{j}$-th periods; $\mathrm{i}=$ interest rate; $\mathrm{j}=\mathrm{j}$-th period, in year; and $\mathrm{n}=$ number of periods, in years.

We also performed a sensitivity analysis, in which NPV and ANPV were computed considering four interest rates usually adopted in forest investments in Brazil, being: $\mathrm{i}=8 \%, 9 \%, 10 \%$, and 11\% (LIMA JUNIOR; REZENDE; OLIVEIRA, 1997). Another reason to use such rates is that, for a long time, banks in Brazil provide interest rates of many investments ranging between these rates considered here. Therefore, a sensitivity analysis allows us to compare selected regimes with another investment, as a bank one.

To calculate NPV and ANPV, returns and costs of pine plantations in the south of Brazil were considered. The costs were based on a market research carried out by the enterprise Brasil Florestal Engenharia de Projetos, considering 2013 market prices in the south of Brazil. We considered: planting cost, taking into account manual application of herbicide pre- and post-planting, besides the cost of the planting itself; replanting; harvesting costs, in which mechanized operations were considered both for thinnings as for clear cuts and loadings to forest stand boundaries. In this research, we did not consider transportation cost because it depends on quite variable factors, such as forest-industry distance, fuel price, availability of trucks, among others. Prices of all silvicultural activities are described in Table 1.

TABLE 1: Costs of silvicultural activities in loblolly pine plantations.

\begin{tabular}{|c|c|c|}
\hline Activity & Age of activity & $\operatorname{Cost}^{1}$ \\
\hline Density (1,111 plants/ha) & 0 & $\mathrm{R} \$ 1,609.4 / \mathrm{ha}$ \\
\hline Density (1,600 plants/ha) & 0 & $\mathrm{R} \$ 1,994.5 / \mathrm{ha}$ \\
\hline Density (2,000 plants/ha) & 0 & $\mathrm{R} \$ 2,309.5 / \mathrm{ha}$ \\
\hline Density (2,500 plants/ha) & 0 & $\mathrm{R} \$ 2,703.3 / \mathrm{ha}$ \\
\hline \multicolumn{3}{|l|}{$1^{\text {st }}$ thinning } \\
\hline $5^{\text {th }}$ line $+30 \%$ from below & $7-9 / 13-15 / 18-20$ & $\mathrm{R} \$ 34.0 / \mathrm{m}^{3}$ \\
\hline $5^{\text {th }}$ line $+45 \%$ from below & $7-9 / 13-15 / 18-20$ & $\mathrm{R} \$ 34.0 / \mathrm{m}^{3}$ \\
\hline $5^{\text {th }}$ line $+60 \%$ from below & $7-9 / 13-15 / 18-20$ & $\mathrm{R} \$ 34.0 / \mathrm{m}^{3}$ \\
\hline \multicolumn{3}{|l|}{$2^{\text {nd }}$ thinning } \\
\hline $30 \%$ from below & $13-15 / 18-20$ & $\mathrm{R} \$ 29.0 / \mathrm{m}^{3}$ \\
\hline $45 \%$ from below & $13-15 / 18-20$ & $\mathrm{R} \$ 29.0 / \mathrm{m}^{3}$ \\
\hline $60 \%$ from below & $13-15 / 18-20$ & $\mathrm{R} \$ 29.0 / \mathrm{m}^{3}$ \\
\hline \multicolumn{3}{|l|}{$3^{\text {rd }}$ thinning } \\
\hline $30 \%$ from below & $18-20$ & $\mathrm{R} \$ 26.5 / \mathrm{m}^{3}$ \\
\hline $45 \%$ from below & $18-20$ & $\mathrm{R} \$ 26.5 / \mathrm{m}^{3}$ \\
\hline $60 \%$ from below & $18-20$ & $\mathrm{R} \$ 26.5 / \mathrm{m}^{3}$ \\
\hline ar cut & $12-15 / 17-20 / 22-25$ & $\mathrm{R} \$ 23.0 / \mathrm{m}^{3}$ \\
\hline
\end{tabular}

TABELA 1: Custos de atividades silviculturais em plantações de Pinus taeda.

Where in: 'Brasil Florestal Engenharia de Projetos: costs based on 2013 market prices. 
In relation to the returns needed, we assigned different $\log$ prices following assortment classes, once the outcomes are given according to the log dimension, as reported before. The outcomes also distinguish yields from thinnings and from clear cut, both used in the calculation of returns and costs during and in the end of the period of production. As the regimes yield not only high-value logs (which is our focus), ANPV was calculated considering returns and costs associated to all the log assortments. Dimensions and prices by log assortment are presented in Table 2 .

TABLE 2: Descriptions of dimensions and prices by log assortment.

TABELA 2: Descrição de dimensões e preços por sortimento de tora.

\begin{tabular}{|c|c|c|c|c|}
\hline \multirow[t]{2}{*}{ Log assortment } & \multirow[t]{2}{*}{ Price $\left(\mathrm{R} \$ / \mathrm{m}^{3}\right)$} & \multirow[t]{2}{*}{ Length (m) } & \multicolumn{2}{|c|}{$\begin{array}{l}\text { Diameter } \\
(\mathrm{cm})\end{array}$} \\
\hline & & & Minor & Major \\
\hline Veneer $^{1}$ & 141.4 & 2.5 & 35.1 & - \\
\hline Saw type- $3^{1}$ & 129.6 & 2.5 & 25.1 & 35.0 \\
\hline Saw type-- $2^{1}$ & 100.9 & 2.5 & 18.1 & 25.0 \\
\hline Saw type- $1^{1}$ & 70.4 & 2.4 & 8.1 & 18.0 \\
\hline Residue $^{2}$ & 8.0 & 1.0 & 5.0 & 8.0 \\
\hline
\end{tabular}

Where in: ${ }^{1}$ SEAB (2013); ${ }^{2}$ Brasil Florestal Engenharia de Projetos (2013).

\section{RESULTS}

We presented the results of production by planting spacing due to the large number of simulations, resulting in 729 simulated management regimes by planting spacing (2,916 in total). The following figures show scatterplots containing bubbles that represent each of the management regimes. The bubble size is proportional to the thinning intensity, in which the smallest bubbles represent regimes with lighter thinnings, i. e., $30 \%$ removal of trees. The biggest bubbles consequently represent the regimes with heavier thinnings, i. e., $60 \%$ removal of trees. In this way, these scatterplots approach perspectives of production in relation to the thinning intensities. Likewise, a perspective in relation to the age of thinnings was also illustrated, in which the smallest bubbles represent regimes with earlier thinnings $(7,13$, and 18 years, respectively) and the largest ones refer to the later thinnings $(9,15$, and 20 years, respectively). In addition, we separated the management regimes according to the intensity of removal from below $(30 \%, 45 \%$, or $60 \%)$ of the first thinning, aiming to detect its effect on the high-value log production. The following figures illustrate the volume of these logs in regimes with 1,$111 ; 1,600 ; 2,000$ and 2,500 plants/ha, in both perspectives (intensity and age of thinning). 
Perspective of the thinning intensities
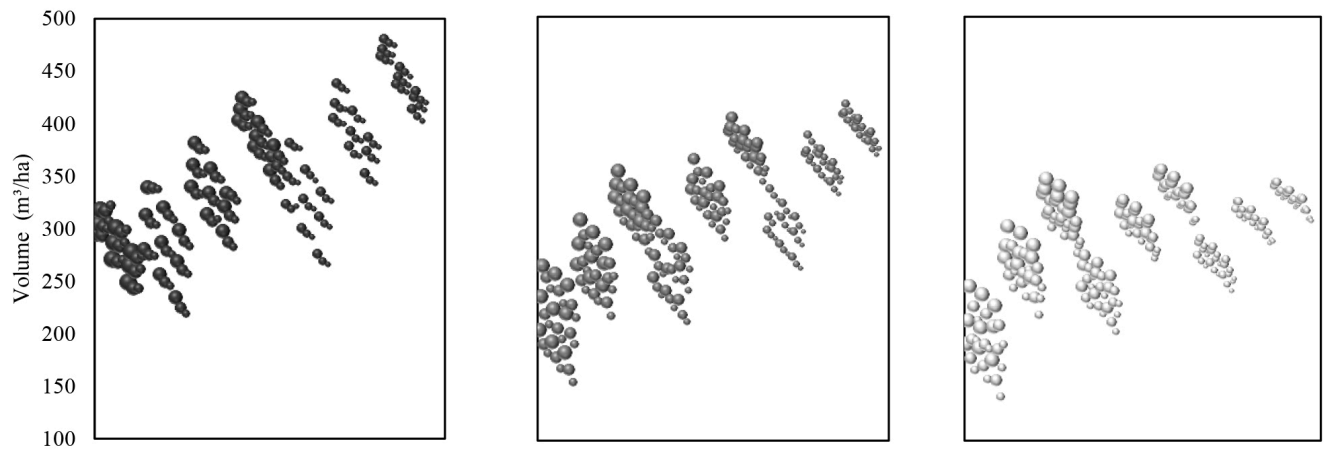

Perspective on the age of thinning
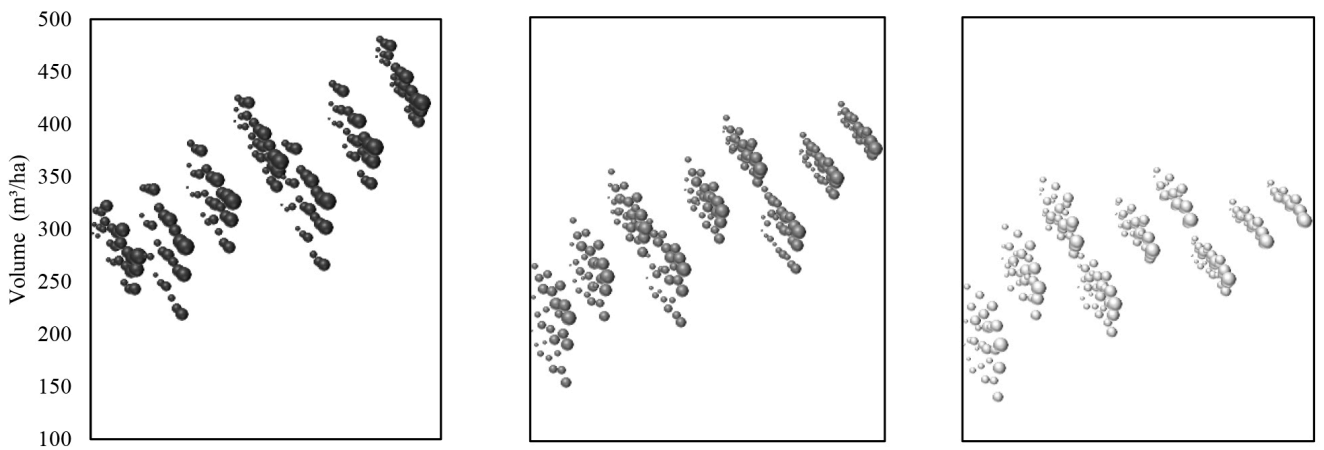

FIGURE 2: Large diameter log volumes in simulated regimes for Pinus taeda L. with planting density of 1,111 plants/ ha, managed at 25 years old and subjected to different thinning regimes. Bubble size is proportional to the intensity and the age of thinning. Left-side graphic: First thinning is the heaviest one, whereas the second and third thinnings range from light to heavy. Middle graphic: First thinning is moderate, whereas the second and third thinnings range from light to heavy. Right-side graphic: First thinning is the lightest one, whereas the second and third thinnings range from light to heavy.

FIGURA 2: Volume de toras grossas em regimes simulados para Pinus taeda L. com densidade de plantio de 1.111 plantas/ha, manejados até 25 anos de idade e sujeitos a diferentes regimes de manejo. O tamanho da bolha é proporcional à intensidade e ao tempo de aplicação dos desbastes. Gráfico da esquerda: Primeiro desbaste é o mais pesado, enquanto o segundo e o terceiro variam de leve a pesado. Gráfico central: Primeiro desbaste é moderado, enquanto o segundo e o terceiro variam de leve a pesado. Gráfico da direita: Primeiro desbaste é o mais leve, enquanto o segundo e o terceiro variam de leve a pesado. 
- $1^{\text {st }}$ thinning: $5^{\text {th }}$ line $+60 \%$

- $1^{\text {st }}$ thinning: $5^{\text {th }}$ line $+45 \%$

$1^{\text {st }}$ thinning: $5^{\text {th }}$ line $+30 \%$

Perspective of the thinning intensities
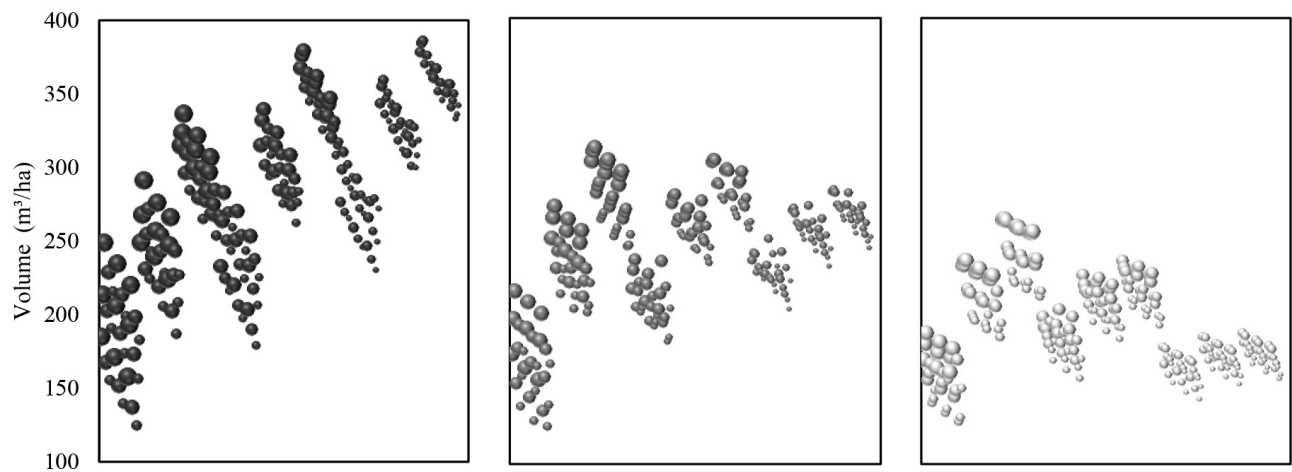

Perspective on the age of thinning
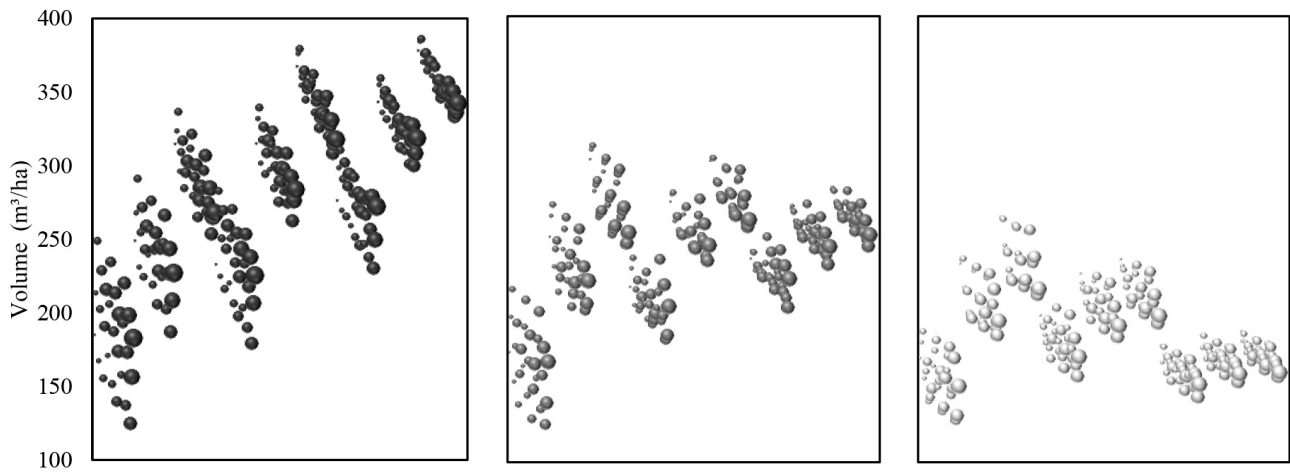

FIGURE 3: Large diameter log volumes in simulated regimes for Pinus taeda L. with planting density of 1,600 plants/ ha, managed at 25 years old and subjected to different thinning regimes. Bubble size is proportional to the intensity and the age of thinning. Left-side graphic: First thinning is the heaviest one, whereas the second and third thinnings range from light to heavy. Middle graphic: First thinning is moderate, whereas the second and third thinnings range from light to heavy. Right-side graphic: First thinning is the lightest one, whereas the second and third thinnings range from light to heavy.

FIGURA 3: Volume de toras grossas em regimes simulados para Pinus taeda L. com densidade de plantio de 1.600 plantas/ha, manejados até 25 anos de idade e sujeitos a diferentes regimes de manejo. O tamanho da bolha é proporcional à intensidade e ao tempo de aplicação dos desbastes. Gráfico da esquerda: Primeiro desbaste é o mais pesado, enquanto o segundo e o terceiro variam de leve a pesado. Gráfico central: Primeiro desbaste é moderado, enquanto o segundo e o terceiro variam de leve a pesado. Gráfico da direita: Primeiro desbaste é o mais leve, enquanto o segundo e o terceiro variam de leve a pesado. 
Perspective of the thinning intensities
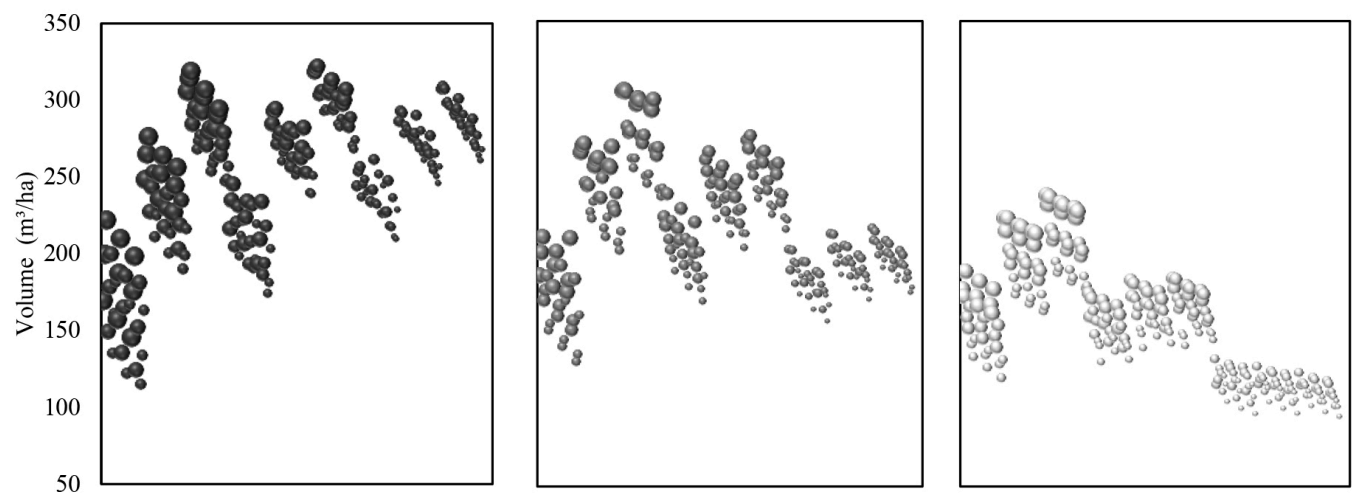

Perspective on the age of thinning
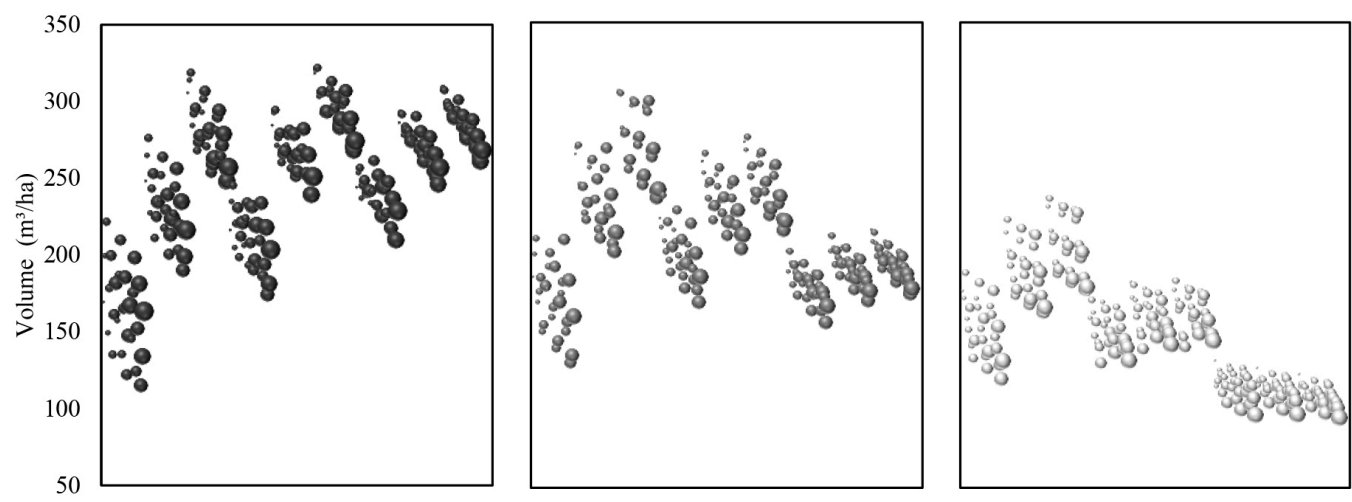

FIGURE 4: Large diameter log volumes in simulated regimes for Pinus taeda L. with planting density of 2,000 plants/ ha, managed at 25 years old and subjected to different thinning regimes. Bubble size is proportional to the intensity and the age of thinning. Left-side graphic: First thinning is the heaviest one, whereas the second and third thinnings range from light to heavy. Middle graphic: First thinning is moderate, whereas the second and third thinnings range from light to heavy. Right-side graphic: First thinning is the lightest one, whereas the second and third thinnings range from light to heavy.

FIGURA 4: Volume de toras grossas em regimes simulados para Pinus taeda L. com densidade de plantio de 2.000 plantas/ha, manejados até 25 anos de idade e sujeitos a diferentes regimes de manejo. O tamanho da bolha é proporcional à intensidade e ao tempo de aplicação dos desbastes. Gráfico da esquerda: Primeiro desbaste é o mais pesado, enquanto o segundo e o terceiro variam de leve a pesado. Gráfico central: Primeiro desbaste é moderado, enquanto o segundo e o terceiro variam de leve a pesado. Gráfico da direita: Primeiro desbaste é o mais leve, enquanto o segundo e o terceiro variam de leve a pesado. 
- $1^{\text {st }}$ thinning: $5^{\text {th }}$ line $+60 \%$

- $1^{\text {st }}$ thinning: $5^{\text {th }}$ line $+45 \%$

$1^{\text {st }}$ thinning: $5^{\text {th }}$ line $+30 \%$

Perspective of the thinning intensities
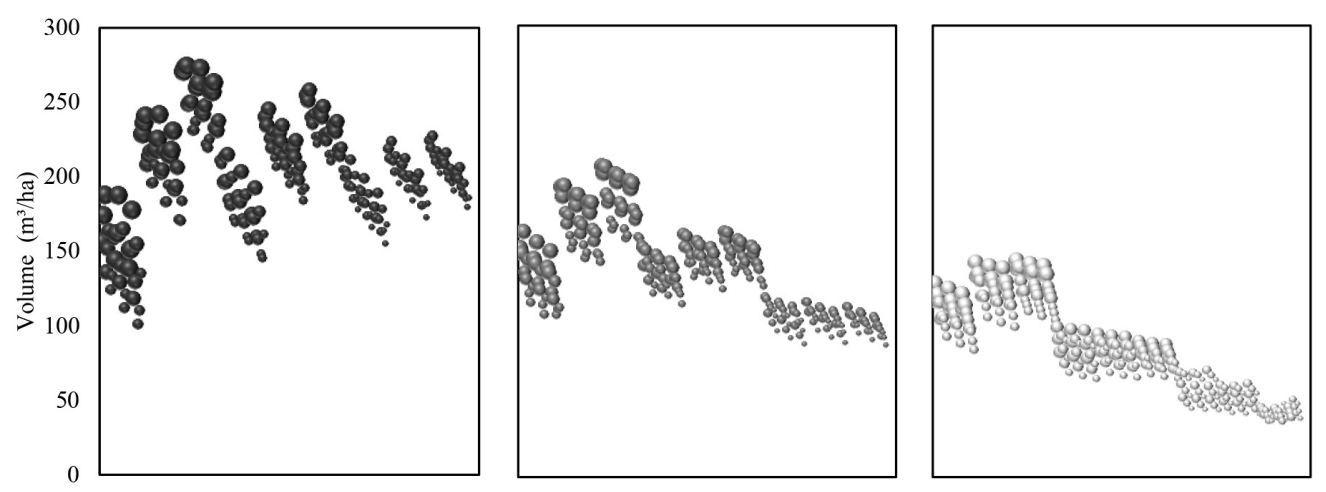

Perspective on the age of thinning
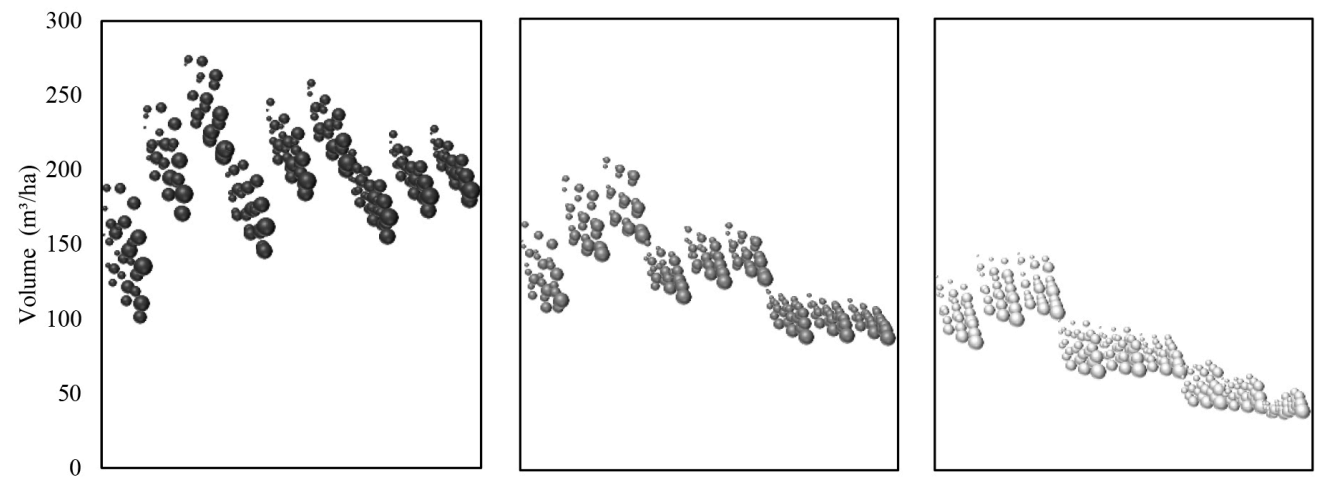

FIGURE 5: Large diameter log volumes in simulated regimes for Pinus taeda L. with planting density of 2,500 plants/ ha, managed at 25 years old and subjected to different thinning regimes. Bubble size is proportional to the intensity and the age of thinning. Left-side graphic: First thinning is the heaviest one, whereas the second and third thinnings range from light to heavy. Middle graphic: First thinning is moderate, whereas the second and third thinnings range from light to heavy. Right-side graphic: First thinning is the lightest one, whereas the second and third thinnings range from light to heavy.

FIGURA 5: Volume de toras grossas em regimes simulados para Pinus taeda L. com densidade de plantio de 2.500 plantas/ha, manejados até 25 anos de idade e sujeitos a diferentes regimes de manejo. O tamanho da bolha é proporcional à intensidade e ao tempo de aplicação dos desbastes. Gráfico da esquerda: Primeiro desbaste é o mais pesado, enquanto o segundo e o terceiro variam de leve a pesado. Gráfico central: Primeiro desbaste é moderado, enquanto o segundo e ao terceiro variam de leve a pesado. Gráfico da direita: Primeiro desbaste é o mais leve, enquanto o segundo e o terceiro variam de leve a pesado.

Considering all the planting densities, we found an expressive variation in volume of large diameter logs. Regimes with denser spacing produced less volume than the regimes with less dense spacing, such as follows: 1,111 plants/ha - from $\sim 140$ to $\sim 480 \mathrm{~m}^{3} / \mathrm{ha} ; 1,600 \mathrm{plants} / \mathrm{ha}-$ from $\sim 125$ to $\sim 385 \mathrm{~m}^{3} / \mathrm{ha}$; 2,000 plants $/$ ha - from $\sim 85$ to $320 \mathrm{~m}^{3} / \mathrm{ha} ; 2,500 \mathrm{plants} / \mathrm{ha}$ - from $\sim 35$ to $\sim 275 \mathrm{~m}^{3} / \mathrm{ha}$. Table 3 presents results of the five most productive management regimes by planting density, including thinning descriptions, age of application and intensity (\%) of removal from below, as well total and large diameter log volumes. The regimes presented in Table 3 are optimal by producing a maximum large diameter log volume. 
TABLE 3: Thinning ages and thinning intensities of the best regimes for the production high-value logs.

TABELA 3: Idade e intensidade de aplicação de desbastes dos melhores regimes para produção de toras grossas.

\begin{tabular}{|c|c|c|c|c|c|c|c|c|c|c|c|c|}
\hline \multirow{2}{*}{$\begin{array}{l}\text { Planting } \\
\text { density }\end{array}$} & \multirow{2}{*}{$\begin{array}{l}\text { Optimal } \\
\text { regime }\end{array}$} & \multicolumn{3}{|c|}{$1^{\text {st }}$ thinning ${ }^{\mathrm{a}, \mathrm{b}}$} & \multicolumn{3}{|c|}{$2^{\text {nd }}$ thinning ${ }^{\mathrm{b}}$} & \multicolumn{3}{|c|}{$3^{\text {rd }}$ thinning ${ }^{\mathrm{b}}$} & \multirow{2}{*}{$\begin{array}{c}\text { Large } \\
\text { diameter log } \\
\text { volume }\left(\mathrm{m}^{3} /\right. \\
\text { ha })\end{array}$} & \multirow{2}{*}{$\begin{array}{c}\text { Total } \\
\text { volume } \\
\left(\mathrm{m}^{3} / \mathrm{ha}\right)\end{array}$} \\
\hline & & 7 & 8 & 9 & 13 & 14 & 15 & 18 & 19 & 20 & & \\
\hline \multirow{5}{*}{ 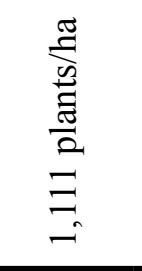 } & 1 & 60 & & & 30 & & & & & 30 & 481.1 & $1,030.9$ \\
\hline & 2 & 60 & & & & 30 & & & & 45 & 477.0 & $1,037.1$ \\
\hline & 3 & 60 & & & & & 30 & & & 60 & 475.0 & $1,043.0$ \\
\hline & 4 & 60 & & & 30 & & & & 30 & & 471.3 & $1,022.1$ \\
\hline & 5 & 60 & & & & 60 & & & 45 & & 466.7 & $1,028.1$ \\
\hline \multirow{5}{*}{ 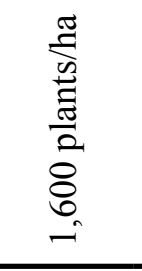 } & 1 & 60 & & & 30 & & & & & 60 & 386.2 & $1,181.7$ \\
\hline & 2 & 60 & & & 30 & & & & 60 & & 384.8 & $1,175.0$ \\
\hline & 3 & 60 & & & 45 & & & & & 60 & 379.5 & $1,135.2$ \\
\hline & 4 & 60 & & & 30 & & & 60 & & & 378.6 & $1,169.9$ \\
\hline & 5 & 60 & & & & 30 & & & & 45 & 376.5 & $1,187.9$ \\
\hline \multirow{5}{*}{ 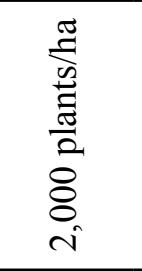 } & 1 & 60 & & & 45 & & & & & 60 & 322.2 & $1,230.7$ \\
\hline & 2 & 60 & & & 45 & & & & 60 & & 321.0 & $1,223.7$ \\
\hline & 3 & 60 & & & 60 & & & & & 60 & 319.0 & $1,168.9$ \\
\hline & 4 & 60 & & & 45 & & & 60 & & & 318.7 & $1,220.4$ \\
\hline & 5 & 60 & & & 60 & & & & 60 & & 314.2 & $1,161.1$ \\
\hline \multirow{5}{*}{ 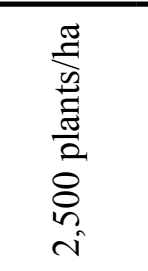 } & 1 & 60 & \multirow{5}{*}{60} & & 60 & & & & & 60 & 274.5 & $1,240.1$ \\
\hline & 2 & 60 & & & 60 & & & & & 60 & 273.5 & $1,233.7$ \\
\hline & 3 & & & & 60 & & & & & 60 & 273.1 & $1,266.4$ \\
\hline & 4 & 60 & & & 60 & & & 60 & & & 270.8 & $1,228.6$ \\
\hline & 5 & & & 60 & 60 & & & & & 60 & 263.5 & $1,290.1$ \\
\hline
\end{tabular}

Where in: $a=$ Systematic thinning (at every fifth row) plus thinning from below; $b=$ Intensity (\%) of removal from below.

As shown in Table 3, the most productive regimes with 1,111 and 2,500 plants/ha provided, respectively, high-value log volumes equal to 481.1 and $263.5 \mathrm{~m}^{3} / \mathrm{ha}$, an expressive difference of $\sim 45 \%$. On the other hand, differences in total volume were not so expressive in relative values, reaching $\sim 25 \%$. The findings reveal a clear trend in decreasing the production of large diameter log from less to denser regimes, however, the total volume was maximized in denser regimes.

Regarding to the thinning regimes, we noted that most of the optimal regimes presented at least two thinnings from below with $60 \%$ removal of the remaining trees (Table 3 ). To attain an optimal productivity in high-value logs, the findings indicated that the first thinning must be as heavier and earlier as possible (figures 2 to 5; Table 3), regardless of the planting density. In the second thinning, the lighter intensities tended to be better in less dense forests than in denser ones, but this trend was weaker in the third thinning. The first thinning tended to be more steady, since variations in intensity and age of application were greater in the second and third thinnings (Table 3), meaning that managers face riskier decisions in the choice of proper periods and intensities for thinning forests for the second and third time.

Among the five most productive regimes with 1,111 plants/ha, the second thinning had opposite behavior comparing to the first one, where heavier thinnings were more frequent among these highlighted regimes. In regimes with 1,600 and 2,000 plants/ha, the thinnings were relatively similar in respect of intensity and age of application, suggesting that these two planting intensities are more similar among the 
four examined ones. As expected, regimes with 2,500 plants/ha presented heaviest thinnings in all optimal regimes, but not the earliest ones.

ANPV of the best regimes was calculated considering four different interest rates as showed in Table 4. The smallest and highest values were respectively $\sim 1,300$ and $\sim 2,100 \mathrm{R} \$ /$ ha, but for a same interest rate, ANPV ranged on average $\sim 300 \mathrm{R} \$ /$ ha among the planting densities. The variation of interest rates affected the ANPVs in up to $\sim 530 \mathrm{R} \$ /$ ha in a same optimal regime.

TABLE 4: Variation of Annualized Net Present Value with different of interest rates for the optimal regimes.

TABELA 4: Variação de Valor Presente Líquido Anualizado ( $\mathrm{R} \$ / \mathrm{ha})$ com diferentes taxas de interesse para os regimes ótimos.

\begin{tabular}{|c|c|c|c|c|c|c|}
\hline \multirow{2}{*}{$\begin{array}{l}\text { Planting } \\
\text { density }\end{array}$} & \multirow{2}{*}{$\begin{array}{l}\text { Optimal } \\
\text { regime }\end{array}$} & \multicolumn{4}{|c|}{ Interest rate } & \multirow{2}{*}{$\begin{array}{l}\text { Absolute } \\
\text { amplitude }\end{array}$} \\
\hline & & $8 \%$ & $9 \%$ & $10 \%$ & $11 \%$ & \\
\hline \multirow{5}{*}{ 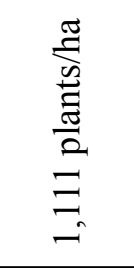 } & 1 & $1,820.4$ & $1,644.8$ & $1,484.4$ & $1,337.9$ & 482,5 \\
\hline & 2 & $1,831.6$ & $1,653.5$ & $1,490.6$ & $1,341.8$ & 489,8 \\
\hline & 3 & $1,829.9$ & $1,649.3$ & $1,484.1$ & $1,333.2$ & 496,7 \\
\hline & 4 & $1,823.1$ & $1,650.1$ & $1,491.8$ & $1,346.9$ & 476,2 \\
\hline & 5 & $1,834.6$ & $1,659.1$ & $1,498.4$ & $1,351.2$ & 483,4 \\
\hline \multirow{5}{*}{ 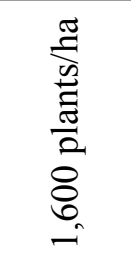 } & 1 & $1,925.0$ & $1,731.5$ & $1,554.7$ & $1,393.1$ & 531,9 \\
\hline & 2 & $1,938.7$ & $1,746.9$ & $1,571.3$ & $1,410.5$ & 528,2 \\
\hline & 3 & $1,969.6$ & $1,790.0$ & $1,624.3$ & $1,471.3$ & 498,3 \\
\hline & 4 & $1,947.0$ & $1,757.2$ & $1,583.2$ & $1,423.7$ & 523,3 \\
\hline & 5 & $1,932.2$ & $1,736.1$ & $1,556.7$ & $1,392.7$ & 539,5 \\
\hline \multirow{5}{*}{ 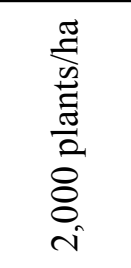 } & 1 & $2,033.4$ & $1,842.9$ & $1,666.9$ & $1,504.5$ & 528,9 \\
\hline & 2 & $2,041.8$ & $1,853.1$ & $1,678.6$ & $1,517.1$ & 524,7 \\
\hline & 3 & $2,053.2$ & $1,880.6$ & $1,719.3$ & $1,568.4$ & 484,8 \\
\hline & 4 & $2,047.6$ & $1,860.8$ & $1,687.8$ & $1,527.6$ & 520 \\
\hline & 5 & $2,055.6$ & $1,885.0$ & $1,725.3$ & $1,575.6$ & 480 \\
\hline \multirow{5}{*}{ 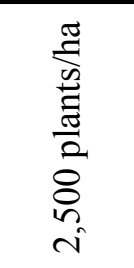 } & 1 & $2,045.8$ & $1,865.0$ & $1,696.0$ & $1,538.0$ & 507,8 \\
\hline & 2 & $2,051.5$ & $1,872.3$ & $1,704.5$ & $1,547.4$ & 504,1 \\
\hline & 3 & $2,074.9$ & $1,896.5$ & $1,729.4$ & $1,572.7$ & 502,2 \\
\hline & 4 & $2,053.5$ & $1,876.1$ & $1,709.8$ & $1,553.9$ & 499,6 \\
\hline & 5 & $2,103.8$ & $1,926.1$ & $1,758.9$ & $1,601.8$ & 502 \\
\hline
\end{tabular}

\section{DISCUSSION}

\section{Effect of density and thinning regimes on timber production}

The findings show that the production of large diameter logs is inversely related to the planting density, decreasing as much as the density increased; 1,111 trees/ha highlighted as the optimal density. So, forest managers must consider that thinning is not the only silvicultural activity for maximizing production of large diameter logs (LEITE; NOGUEIRA; MOREIRA, 2006; PAULESKI, 2010), since no thinning regime applied to denser forests attained the best production in the less dense regimes $(1,111$ trees $/ \mathrm{ha})$. In other words, planting density also contributes to attain an optimal high-value log production. Similar to our results, Sanquetta et al. (1998) used a database from experimental plots in the state of Parana to simulate (also by means of the software SisPinus ${ }^{\circledR}$ ) the effect of planting densities on the log production for veneer; 
they obtained statistical differences in volume of up to $\sim 10$ times between the densities 3,333 and 909 plants/ha. The authors also assessed interactions between planting density and thinning regimes, noting that treatments without and with one or two thinnings yield statistically equal large diameter log volumes. They concluded that the spacings of $2.5 \times 2.8$ to $2.5 \times 4.4$ are ideal to maximize the production of large diameter logs, either with or without applying thinnings.

Although, we only considered regimes with thinnings, what prevent us to compare to the results without thinnings from Sanquetta et al. (1998), our results indicate the importance in carrying particular thinning regimes according to the planting density. For example, in regimes with planting density of 2,500 plants/ha, the best and worst thinning regimes were responsible for a difference in the production of highvalue $\log$ around seven times (Figure 5). Such variation decreased from high- to low-density regimes, in which regimes with 1,111 plants/ha reached a maximum difference in volume around three and a half times (Figure 2). Among the five most productive regimes with 2,500 plants/ha, in two of them the age of the first thinning ( 8 and 9 years) was later than the other ones. This is an unexpected event in high-density planting, where the optimization should prioritize earlier thinnings in highly stocked forests. However, we have to consider that the simulator SisPinus ${ }^{\circledR}$ have mortality models included in its system, which ends up inducing thinnings to be postponed or to have lighter intensities, since such regimes are very susceptible to tree mortality caused by self-thinning (SCHNEIDER et al., 2009). Thus, perhaps the optimal age of the first thinning may be earlier than 7 years, i. e., in a period when the forest did not reach a maximum mortality caused by self-thinning.

In general, figures 2 to 5 show that early thinnings tend to be more efficient for obtaining large diameter logs in all planting densities, as well as the heavier thinnings. However, age of application showed to be more important in high-density regimes. It is important to highlight that despite thinnings stimulate the tree diameter to grow in faster rates, oftentimes thinnings should not be applied when a forest is managed aiming to maximize total timber volume, disregarding log diameters, such as addressed by David et al. (2017a) and Elesbão and Schneider (2011). In addition, we point out that timber production is associated with soil nutrients, light and water available in medium- and high-quality sites (ACERBI JUNIOR et al., 2002), therefore, we must take into account that the behavior of regimes changes among sites of different qualities (GOMES; MAESTRI; SANQUETTA, 1997; SANQUETTA et al., 1998; DAVID et al., 2017b).

\section{Economic implications of optimal management regimes}

Our findings show that maximizing production of high-value logs does not mean maximizing ANPV. As the total volumes were proportional to the planting density (Table 3), the denser regimes ended up presenting greater ANPVs, comparing to the less dense ones. Such relation was expected and is addressed in researches as Gomes, Maestri and Sanquetta (1997). The fact is that the price we adopted for the assortment class 'veneer log' did not overcome the higher revenues from finer and cheaper logs, which are majority in denser regimes. In an economic point of view, it is important to highlight that foresters that plant to sell timber have different end goals than companies that plant for their own consumption, where many other economic issues are taken into account. To these companies, the timber harvested is just the mid of a production chain and value will be added to their timber after industry processes. To foresters, in turn, our findings suggest that planting forests seeking to maximize total volume is more economically feasible than maximizing high-value log volume. Obviously, this statement is valid for costs and prices of logs around which we used in the simulations.

It is usual forestry companies and managers make forest investments considering long time horizons, even knowing that market prices of logs may vary in a relatively short time. In the south of Brazil, some companies bet in the business of clean wood, hoping that fine timber products will lack in the future. Forests destined to clean wood require pruning and selective thinnings that increase the production costs, and this creates an uncertain scenario that should be more carefully analyzed, but in fact, it has been oftentimes underrepresented or disregarded (HILDEBRANDT; KNOKE, 2011). In this scope, modelling growth and yield under different management regimes has commonly been a neglected task, as exposed by Hildebrandt and Knoke (2011). SisPinus ${ }^{\circledR}$ plays an important role to this, since it possesses a massive database from pine plantations in southern Brazil, besides allowing us to incorporate equations generated from particular forest 
data, such as dominant height and taper equations.

In addition to the modelling issues, simulating variations of interest rates to assess economically forest investments also contributes, among others, to define thinning regimes, once there is a trend in increasing the number of thinnings, when high interest rates and long rotation forests are considered (DAVID et al., 2017a). As our analysis involves only simulations with three thinnings, we cannot examine the need for thinnings as a response to the variation of interest rates, but in respect of planting density, interest rates had low impact, presenting generally an amplitude of $\sim 500 \mathrm{R} \$ /$ ha (Table 4). Vitale and Miranda (2010) discussed the relation between thinning and interest rate by assessing economically pine and eucalyptus rotations also in the state of Parana. The authors noted that the regimes with revenues obtained from early thinnings overcame the ones that were thinned later; consequently, one suffered more influence of the interest rate than the other did.

\section{CONCLUSIONS}

To manage pine forests in the south of Brazil aiming to maximize the production of large diameter logs, the manager must opt for low-density regimes (1,111 plants/ha); they provide the highest productions of large diameter logs. In addition, such low-density regimes present fewer uncertainties in the choice of the intensity and age of the first thinning than high-density regimes. It means that improper intensity or age of the first thinning can affect the log production more in high-density regimes than in the low-dense ones. The management regime that provided the highest production of large diameter logs highlighted by containing: 1,111 plants/ha; heavy first thinning ( $5^{\text {th }}$ line $+60 \%$ removal from below), at 7 years old; light second thinning (30\%), at 13 years old; light third thinning (30\%), at 20 years of age.

Considering high-quality sites and the costs and returns used here, managing pine forests seeking to maximize total volume is more profitable than maximizing large diameter log volume; in this case, denser regimes $(1,600$ or 2,500 plants/ha) should be preferred. Even applying the highest interest rate (11\%), all regimes were profitable.

\section{REFERENCES}

ACERBI JUNIOR, F. W. et al. Modelo para prognose econômica e da produção e análise econômica de regimes de manejo para Pinus taeda L. Revista Árvore, Viçosa, MG, v. 26, n. 6, p. 699-713, 2002.

ACUÑA, E.; DRAKE, F. Análisis de riesgo en la gestión forestal e inversiones silviculturales: una revisión bibliográfica. Bosque, Valdivia, v. 24, n. 1, p. 113-124, 2003.

BORDEAUX, J. M.; LORENZ, W. W.; DEAN, J. F. D. Biomarker genes highlight intraspecific and interspecific variations in the responses of Pinus taeda L. and Pinus radiata D. Don to Sirex noctilio F. acid gland secretions. Tree physiology, Oxford, v. 32, p. 1302-1312, 2012.

CORTE, A. P. D.; SANQUETTA, C. R. Quantificação do estoque de carbono fixado em reflorestamentos de pinus na área de domínio da Floresta Ombrófila Mista no Paraná. Cerne, Viçosa, MG, v. 13, n. 1, p. 32-39, 2007.

DAVID, H. C. et al. Economic analysis and revenue optimization in management regimes of Pinus taeda. Revista Ceres, Viçosa, MG, v. 64, n. 3, p. 222-231, 2017 a.

DAVID, H. C. et al. Efeito da qualidade do sítio e do desbaste na produção de pinus. Floresta e Ambiente, Seropédica, v. 24, p. e00096414, 2017 b.

DAVID, H. C. et al. Updating of dominant height growth modeling and site index of Pinus taeda L. in southern Brazil. AJBAS, [s. 1.], v. 9, n. 2, p. 115-125, 2015.

DOSSA, D. et al. Aplicativo com análise de rentabilidade para sistemas de produção de florestas cultivadas

e de grãos. Colombo: Embrapa Florestas, 2000, 56p. (Embrapa Florestas. Documentos, 39).

ELESBÃO, L. E. G.; SCHNEIDER P. R. Produção do Pinus taeda L. em povoamento desbastado na região dos Campos de Cima da Serra, Rio Grande do Sul. Ciência Florestal, Santa Maria, v. 21, n. 1, p. 119-124, 2011.

GOMES, F. S.; MAESTRI, R.; SANQUETTA, C. R. Avaliação da produção em volume total e sortimento 
em povoamentos de Pinus taeda L. submetidos a diferentes condições de espaçamento inicial e sítio. Ciência Florestal, Santa Maria, v. 7, n. 1, p. 101-126, 1997.

HILDEBRANDT, P.; KNOKE, T. Investment decisions under uncertainty - A methodological review on forest science studies. Forest Policy and Economics, Amsterdam, v. 13, p. 1-15, 2011.

LEITE, H. G.; NOGUEIRA G. S.; MOREIRA, A. M. Efeito do espaçamento e da idade sobre variáveis de povoamentos de Pinus taeda L. Revista Árvore, Viçosa, MG, v. 30, n. 4, p. 603-612, 2006.

LIEBSCH, D. et al. Descascamento de Pinus taeda por macacos-prego (Sapajus nigritus): tipos e intensidades de danos e seus impactos sobre o crescimento das árvores. Scientia Forestalis, Piracicaba, v. 105, p. 37-49, 2015.

LIMA JUNIOR, V. B.; REZENDE, J. L. P.; OLIVEIRA, A. D. Determinação da taxa de desconto a ser usada na análise econômica de projetos florestais. Revista Cerne, Lavras, v. 3, n. 1, p. 45-66, 1997.

OLVEIRA, E. B. Softwares para manejo e análise econômica de plantações florestais. Colombo: Embrapa Florestas, 2011. (Documentos Embrapa Florestas, 216).

PALAHÍ, M.; PUKKALA, T. Optimising the management of Scots pine (Pinus sylvestris L.) stands in Spain based on individual-tree models. Annals of Forest Science, Les Ulis, v. 60, n. 2, p. 105-114, 2003.

PAULESKI, D. T. Influência do Espaçamento sobre o crescimento e a qualidade da madeira de Pinus taeda L. 2010. 196 f. Tese (Doutorado em Manejo Florestal) - Universidade Federal de Santa Maria, Santa Maria, 2010.

PUKKALA, T.; MIINA, J. Tree-selection algorithms for optimizing thinning using a distance-dependent growth model. Canadian Journal of Forest Research, Ottawa, v. 43, n. 8, p. 719-730, 2013.

SANQUETTA, C. R. et al. Produção de madeira para laminação em povoamentos de Pinus taeda submetidos a diferentes densidades e regimes de desbaste: uma abordagem experimental. Revista Floresta, Viçosa, MG, v. 28, n. 12, p. 83-99, 1998.

SCHNEIDER, P. S. P. et al. Diagrama de manejo da densidade para povoamentos de Pinus taeda L. conduzido sem desbaste. Ciência Florestal, Santa Maria, v. 19, n. 4, p. 433-477, 2009.

SILVA, M. L.; JACOVINE, L. A. G.; VALVERDE, S. R. Economia Florestal. Viçosa, MG: UFV, 2005. SOALLEIRO, R. R.; GONZALEZ, J. G. A; SCHRÖDER, J. Simulation and comparison of silvicultural alternatives for even-aged Pinus pinaster Ait stands in Galicia (Northwestern Spain). Annals of Forest Science, Les Ulis, v. 57, n. 8, p. 747-754, 2000.

VITALE, V.; MIRANDA, G. M. Análise comparativa da viabilidade econômica de plantios de Pinus taeda e Eucalyptus dunnii na região centro-sul do Paraná. Revista Floresta, Curitiba, v. 40, n. 3, p. 469-476, 2010. 